\title{
A consensus on the diagnosis and treatment of acromegaly complications
}

\author{
S. Melmed - F. F. Casanueva $\cdot$ A. Klibanski • \\ M. D. Bronstein $\cdot$ P. Chanson $\cdot$ S. W. Lamberts · \\ C. J. Strasburger $\cdot$ J. A. H. Wass $\cdot$ A. Giustina
}

Published online: 18 August 2012

(c) The Author(s) 2012. This article is published with open access at Springerlink.com

\begin{abstract}
In March 2011, the Acromegaly Consensus Group met to revise and update the guidelines on the diagnosis and treatment of acromegaly complications. The meeting was sponsored by the Pituitary Society and the European Neuroendocrinology Association and included experts skilled in the management of acromegaly. Complications considered included cardiovascular, endocrine and metabolic, sleep apnea, bone diseases, and mortality. Outcomes in selected, related clinical conditions were also considered, and included pregnancy, familial acromegaly and invasive macroadenomas. The need for a new disease staging model was considered, and design of such a tool was proposed.
\end{abstract}

\section{S. Melmed ( $₫)$}

Department of Medicine, Cedars-Sinai Medical Center, 8700 Beverly Blvd., Room 2015, Los Angeles, CA 90048, USA

e-mail: Shlomo.Melmed@cshs.org

\section{F. F. Casanueva}

Division of Endocrinology CHUS, Department of Medicine, Santiago de Compostela University, Santiago de Compostela, Spain

\section{A. Klibanski}

Neuroendocrine Unit, Massachusetts General Hospital and Harvard Medical School, Boston, MA, USA

\section{D. Bronstein}

Neuroendocrine Unit, Division of Endocrinology and Metabolism, University of Sao Paulo Medical School, Sao Paulo, Brazil

P. Chanson

Faculté de Médecine, Université Paris Sud, Orsay, France

P. Chanson

AP-HP, Hôpital Bicêtre, Service d'Endocrinologie et des

Maladies de la Reproduction, Le Kremlin-Bicêtre, France
Keywords Acromegaly · Consensus · Complications · Diagnosis · Treatment

\section{Introduction}

Since 2000, several consensus documents have been published on various aspects of acromegaly management [1-7]. In 2003 a consensus on the diagnosis and treatment of acromegaly complications was published [3], and in March 2011, the Acromegaly Consensus Group that had produced these documents met to revise and update guidelines on acromegaly complications. The meeting was sponsored by the Pituitary Society and the European Neuroendocrinology

\section{P. Chanson \\ Institut National de la Santé et de la Recherche Médicale, U693, Le Kremlin Bicêtre, France}

\section{S. W. Lamberts}

Department of Internal Medicine, Division of Endocrinology,

Erasmus Medical Centre, Rotterdam, The Netherlands

C. J. Strasburger

Department of Endocrinology, Charite Campus Mitte, Berlin, Germany

\section{J. A. H. Wass}

Department of Endocrinology, Oxford Centre of Diabetes, Endocrinology \& Metabolism, Churchill Hospital, Oxford, UK
A. Giustina
Department of Medical and Surgical Sciences, University of Brescia, Brescia, Italy 
Association and included experts skilled in acromegaly management.

Patients with acromegaly have a considerable burden of complications and co-existing illnesses, and factors contributing to increased mortality in acromegaly include higher prevalence of hypertension, hyperglycemia or diabetes, cardiomyopathy and sleep apnea [8]. The diagnosis and management of complications of disease are therefore critical for assuring a favorable long-term outcome for this chronic illness. Current comorbidity issues were discussed by the group and recommendations made for updating the 2003 guidelines.

Recommendations were graded, based on the GRADE system [9, 10], depending on the quality of evidence as very low quality (VLQ; expert opinion with one or a small number of small uncontrolled studies in support), low quality (LQ; large series of small uncontrolled studies), moderate quality (MQ; one or a small number of large uncontrolled studies or meta-analyses), or high quality (HQ; controlled studies or large series of large uncontrolled studies with sufficiently long follow-up). Recommendations were classed as discretionary recommendations (DR) if based on VLQ or LQ evidence, and as strong recommendations (SR) if based on MQ and HQ evidence.

\section{Cardiovascular complications}

Hypertension is highly prevalent, occurring in more than $40 \%$ of patients with acromegaly, and early diagnosis and early aggressive treatment of elevated blood pressure is important irrespective of which acromegaly treatment is employed (HQ) [11-17]. Hypertension in patients with acromegaly is usually mild and readily treated with antihypertensive drugs (VLQ) [3]. The choice of treatment for hypertension should be similar to that in non-acromegaly patients (DR). The effect of different medical treatments for acromegaly on hypertension is as yet unclear (LQ) [15, 18-21]. Sleep apnea, which is present in most patients with acromegaly, exacerbates hypertension (LQ) [22].

Cardiomyopathy is present in most patients with acromegaly, and baseline echocardiogram is indicated. Arrhythmia is rarely a significant clinical challenge in acromegaly (MQ) $[16,23]$. Treatment of acromegaly improves early and intermediate stage myocardial hypertrophy and cardiac dysfunction (HQ) [24-26]. Improvement depends on age, presence of hypertension and duration of the disease (LQ). Recent data (published after the consensus meeting) show that cabergoline does not aggravate prevalence or incidence of valve regurgitation and remodeling [27], which are increased in acromegaly (MQ) [28, 29]. Furthermore, somatostatin receptor ligands (SRLs) may cause asymptomatic bradycardia (LQ) [30]. Rigorous clinical outcome measures (and not only biochemical goals) should be addressed in research studies.
Table 1 Assessment of acromegaly complications at diagnosis and during long-term monitoring

\begin{tabular}{|c|c|}
\hline Diagnosis & During long-term follow-up \\
\hline Blood pressure measurement & $\begin{array}{l}\text { Every } 6 \text { months or when change } \\
\text { of treatment (if hypertensive) }\end{array}$ \\
\hline Echocardiography & Annually \\
\hline ECG & Annually \\
\hline Epworth scale or sleep study & Annually \\
\hline $\begin{array}{l}\text { Echo Doppler of peripheral } \\
\text { arterial and venous system }\end{array}$ & $\begin{array}{l}\text { Annually particularly in } \\
\text { gigantism }\end{array}$ \\
\hline OGTT & $\begin{array}{l}\text { Fasting blood glucose every } \\
6 \text { months (particularly in } \\
\text { uncontrolled disease and during } \\
\text { SRL therapy); } \mathrm{HbA}_{1 \mathrm{c}} \text { every } \\
6 \text { months if diabetes present }\end{array}$ \\
\hline $\begin{array}{l}\text { Total testosterone, SHBG and } \\
\text { prolactin (males) }\end{array}$ & $\begin{array}{l}\text { Annually (free testosterone when } \\
\text { doubts in interpretation of total } \\
\text { testosterone) }\end{array}$ \\
\hline $\begin{array}{l}\mathrm{LH}, \mathrm{FSH}, 17 \beta \text {-estradiol and } \\
\text { prolactin (females) }\end{array}$ & $\begin{array}{l}\text { Annually (or when pregnancy is } \\
\text { desired) }\end{array}$ \\
\hline AcroQoL & Annually \\
\hline DEXA & $\begin{array}{l}\text { Every } 2 \text { years if patient with } \\
\text { osteopenia/osteoporosis }\end{array}$ \\
\hline Thoracic and lumbar spine X-ray & $\begin{array}{l}\text { Every } 2-3 \text { years if osteoporosis } \\
\text { risk factors, kyphosis or } \\
\text { symptoms }\end{array}$ \\
\hline Colonoscopy & $\begin{array}{l}\text { Every } 10 \text { years (more frequently } \\
\text { if IGF-I remains persistently } \\
\text { elevated or if abnormal } \\
\text { colonoscopy or family history } \\
\text { of colonic cancer) }\end{array}$ \\
\hline
\end{tabular}

Genetic screening for markers of familial acromegaly (if suspicion)

ECG electrocardiography, OGTT oral glucose tolerance test, $S R L$ somatostatin receptor ligand, $H b A_{l c}$ glycated hemoglobin, $S H B G$ sex hormone-binding globulin, $L H$ luteinizing hormone, FSH folliclestimulating hormone, AcroQoL Acromegaly Quality of Life Questionnaire, DEXA dual-energy X-ray absorptiometry, IGF-I insulinlike growth factor-I

The following routine baseline assessments are therefore required for patients with acromegaly: electrocardiogram (ECG), echocardiogram, blood pressure measurement, and the Epworth scale or sleep study for sleep apnea (SR) (Table 1). These patients also require assessment of the peripheral arterial system. Particularly in gigantism, there is a need for assessment of vascular disease including peripheral venous disease (DR).

\section{Endocrine and metabolic complications}

\section{Diabetes}

Diabetes occurs more frequently in acromegaly patients than in the general population and is an important predictive factor for increased mortality in patients with acromegaly 
(HQ) $[31,32]$. Treatment of diabetes should be the same in patients with or without acromegaly (DR) [32]. Generally, lowering of growth hormone $(\mathrm{GH})$ levels improves glycemic control and enhances insulin sensitivity (GH is a powerful insulin antagonist), whatever mode of treatment is used (MQ). An exacerbation of carbohydrate intolerance may occur rarely in patients receiving SRLs (MQ) [32-34] (but hyperglycemia occurs more frequently with pasireotide than with other SRLs) [35] and pegvisomant may be considered for treatment of these patients (DR).

\section{Hypogonadism}

Hypogonadism occurs in approximately $50 \%$ of acromegaly patients, but is often reversible unless gonadotroph destruction has occurred (MQ) $[36,37]$. Biochemical diagnosis in males may be difficult, due to low sex hormone-binding globulin levels (making interpretation of total testosterone values more challenging) (LQ) [37]. In these circumstances, assessment of clinical symptoms and bioavailable testosterone are important for diagnosis (DR) (Table 1). Concomitant hyperprolactinemia should be considered as a cause of hypogonadism (MQ). Treatment indications for hypogonadism in acromegaly, and the specific therapy used, should be similar to the non-acromegaly population (DR). In women, hypogonadism should be assessed carefully and treated appropriately, especially if fertility is desired (SR) [36].

\section{Sleep apnea}

Sleep apnea is currently under-assessed, and the prevalence is high (up to $70 \%$ ) in newly diagnosed patients with acromegaly (MQ) [22, 38, 39]. Therefore, every patient should have a careful symptomatic assessment (e.g., by Epworth score), and if necessary laboratory assessment, for sleep apnea at the time of diagnosis, in collaboration with a respiratory physician (SR).

Despite successful acromegaly treatment, sleep apnea does not consistently resolve (MQ), so post-treatment evaluation is essential (SR) [22, 40-43]. Every effort should be made to improve compliance with prescribed treatments including continuous positive air pressure device and other devices (e.g., with appropriate measures tailored to patients with acromegaly, for example, specialized mouth pieces for use during sleep). Consultation with maxillo-facial surgeons is advised, and if necessary, elective surgery should be undertaken.

\section{Other comorbidities and mortality}

Quality of life

Quality of life (QoL) is an important outcome measure in acromegaly [44]. Tools for measuring QoL in patients with acromegaly (e.g., Acromegaly Quality of Life Questionnaire [AcroQoL]) are readily available and should be considered in clinical practice (MQ) (Table 1) [44, 45]. QoL is impaired by GH-excess and GH-deficiency, and therefore, when treating patients, it is important to recognize induction of GH-deficiency, particularly in patients who have undergone previous radiation therapy, as this can have further deleterious effects on subsequent QoL and other parameters (DR) [46].

Bones and joints

Arthropathy affects approximately $75 \%$ of acromegaly patients [47]. Any joint may be affected (large joints, small joints and vertebrae), and range from osteoarthritis to arthralgia to fractures (HQ) [48, 49]. Bony overgrowth and soft-tissue swelling may also lead to nerve entrapment. Such anatomical abnormalities may result in a delay to surgical intervention for acromegaly (LQ). Disability due to acromegaly is probably under-estimated and can affect many aspects of activities of daily living (MQ) [50-52]. Early diagnosis of acromegaly is required to ensure early and aggressive treatment to reduce arthropathy risk, because joint and cartilage changes are irreversible (SR) [53, 54].

Vertebral fractures have been reported to occur in acromegaly patients independently of bone mineral density (BMD) (MQ) [49, 55-57]. Bone size may affect BMD measurement, and the utility of dual-energy X-ray absorptiometry for screening for abnormalities in the absence of size correction is not well documented (LQ). Thoracic and lumbar spine X-ray may be useful for diagnosing spinal deformities, particularly in symptomatic patients (DR) (Table 1). Patients with acromegaly should be evaluated for osteoporosis risk factors including vitamin $\mathrm{D}$ deficiency, inadequate calcium intake, serum calcium to assess hyperparathyroidism, glucocorticoid over-replacement and hypogonadism (SR).

\section{Colon polyps}

Acromegaly is associated with increased colon polyps and may be associated with increased risk of colorectal cancer, but not cancer mortality (MQ) [58]. Colon length may increase during acromegaly resulting in increased mucosal folds (dolichocolon) (LQ) [59, 60]. It is recommended that a screening colonoscopy be carried out at diagnosis in adults (SR). If the colonoscopy is negative, then patients should be screened similarly to the general population, especially if insulin-like growth factor-I (IGF-I) levels are normalized (DR) (Table 1) [59]. If IGF-I remains persistently elevated, more frequent screening is recommended (SR). If colonoscopy is abnormal, follow-up and screening should be in accordance with clinical guidelines [59-61]. 
Mortality

Uncontrolled acromegaly is associated with increased mortality (HQ) [62, 63]. Co-existing adrenal insufficiency and its therapy may have an impact on mortality (LQ). In comparison with other forms of treatment aimed at controlling GH hypersecretion, conventional radiation therapy is specifically associated with increased overall mortality (MQ) [20, 31, 64]. Radiation therapy increases risk of hypopituitarism that leads to higher mortality; including cerebrovascular disease (MQ) [64]. There is a need for more data on mortality outcomes in patients receiving stereotactic radiation therapy, which will become available as more patients are followed-up in the long term.

Minimal dose of glucocorticoids required for efficacy in hypopituitarism should be used, as over-replacement of glucocorticoids can have a negative impact on mortality (LQ). Attention to the GH status is important when using glucocorticoid replacement therapy because higher replacement doses may be required when GH therapy is given (DR) [64].

Improved medical therapy is recommended to control GH/IGF-I levels and improve mortality (SR) [31, 64, 65]. Gonadal, thyroid and GH deficiencies should also be assessed and properly replaced, when indicated (SR).

\section{Treatment outcomes in selected clinical conditions}

\section{Pregnancy}

In women with acromegaly who wish to become pregnant, pituitary function should be assessed and surgical or medical treatment initiated as indicated (SR). There are few data (animal or human) on the safety of pegvisomant in pregnancy (VLQ) [66, 67].

Unless clinically indicated, pharmacological agents should be discontinued on confirmation of pregnancy (SR). In some pregnant women, IGF-I levels remain within the normal range (for non-pregnant women), even in uncontrolled patients, and then increase after delivery. Biochemical assessment of disease activity is of limited value because of placental production of GH and IGF-I (LQ) [68, 69]. There is a need to encourage reporting of outcomes in medically treated pregnant women with acromegaly.

\section{Familial acromegaly}

Familial acromegaly is generally diagnosed at an earlier age than non-familial acromegaly [70], and young patients ( $<30$ years old) with aggressive acromegaly, or individuals with a family member who has a pituitary tumor, should be considered for genetic screening for markers of familial acromegaly (DR). Carney complex, familial isolated pituitary adenoma (FIPA) and multiple endocrine neoplasia type 1 should be considered (DR) [71]. An increased awareness that FIPA is associated with mutations in the aryl hydrocarbon receptor interacting protein (AIP) gene is required [70, 72-74].

Invasive macroadenomas

Access to multimodal treatment and involvement of a multi-disciplinary team are needed in patients with invasive macroadenomas (HQ). If visual fields are impaired, immediate surgery is typically the first line therapy (HQ). Pre-treatment with SRL may improve subsequent surgical outcomes (MQ) [75-77]. Surgical debulking may improve subsequent medical treatment outcomes (LQ) [78-80]. Radiation therapy may continue to have a place in the acromegaly treatment algorithm (MQ) [81-84]. The choice of treatment strategy should include consideration of comorbidities, the projected length of time for hormone normalization, therapy side-effects, pituitary function and cost-benefit of the indicated strategy (DR).

\section{Disease staging}

Biochemical control

Over the past decade, biochemical criteria defining "control' of disease activity have become increasingly rigorous $[4,85]$. The most recent definitions of active disease (random $\mathrm{GH} \geq 1 \mathrm{ng} / \mathrm{ml}$; nadir $\mathrm{GH}$ after oral glucose tolerance test (OGTT) $\geq 0.4 \mathrm{ng} / \mathrm{ml}$; and elevated IGF-I for age) and optimal disease control (random $\mathrm{GH}<1 \mathrm{ng} / \mathrm{ml}$ when treated with SRLs; nadir GH after OGTT $<0.4 \mathrm{ng} / \mathrm{ml}$ after surgery; and age-normalized IGF-I levels for all treatments and as a unique parameter with pegvisomant usage) remain valid (SR) [4, 86]. However, the definition for optimal disease control comes with the caveat that assay-specific normative data for post-OGTT nadir are required (DR).

\section{Tumor control}

The role of tumor characteristics and of optimal tumor growth control has not been fully agreed by consensus. Factors proposed to be associated with disease persistence after surgery and/or a sub-optimal response to medical therapy include:

- Younger age at diagnosis (LQ) [87-89].

- High expression of tumor aggression markers like Ki67, p53 and pituitary tumor transforming gene (PTTG) (LQ) [90-93].

- Sparsely granulated adenomas [94] and hyper-intense imaging on T2 weighted magnetic resonance imaging (MQ) [94-98]. 
- Very large adenomas and actively growing tumors (MQ) [99-103].

- No previous radiation therapy, especially during pegvisomant therapy (LQ) [6, 104-106].

- Previous, sub-optimal response to SRL therapy (LQ) [107-112].

- High GH and IGF-I levels during long-term follow-up (HQ) [102, 103, 107, 108, 110, 113-115].

- Larger tumor remnants after surgery (MQ) [114, 116].

The need for a staging tool?

A new model for describing overall patient assessment before and during treatment would be valuable. The rationale supporting the need for such a model is the requirement to integrate a number of clinical metrics as well as information on pituitary tumor characteristics with the currently used biochemical markers. Ideally, such a model should include data on:

- Clinical symptoms.

- Associated clinical signs and comorbidities.

- GH level.

- IGF-I level.

- Tumor size.

\section{Conclusions}

Effective management of acromegaly complications will lead to decreased morbidity and mortality, and improved QoL. Comprehensive multimodal acromegaly management should integrate biochemical monitoring, careful assessment of tumor behavior and clinical features, and comorbidities.

Acknowledgments The authors thank all participants in the Eighth Acromegaly Consensus Group meeting: Ariel Barkan (USA), Albert Beckers (Belgium), Paolo Beck-Peccoz (Italy), John Bevan (UK), Nienke Biermasz (The Netherlands), Jens Bollerslev (Norway), Vivien Bonert (USA), Francoise Borson-Chazot (France), John Carmichael (USA), Philippe Caron (France), Jens Christiansen (Denmark), David Clemmons (USA), Renato Cozzi (Italy), Maria Vittoria Davi (Italy), Diego Ferone (Italy), Maria Fleseriu (USA), Monica Gadelha (Brazil), Yona Greenman (Israel), Ashley Grossman (UK), Ken Ho (Australia), David Kleinberg (USA), Marta Korbonits (UK), Monica Marazuela Azpiroz (Spain), Gherardo Mazziotti (Italy), Moises Mercado (Mexico), Mark Molitch (USA), Lisa Nachtigall (USA), Stephan Petersenn (Germany), Vera Popovic-Brkic (Serbia), Roberto Salvatori (USA), Janet Schlechte (USA), Michael Sheppard (UK), Gunther Stalla (Germany), Peter Trainer (UK), Mary Lee Vance (USA), Aart Van der Lely (The Netherlands), and Susan Webb (Spain). This study was sponsored by the Pituitary Society and the European Neuroendocrine Association and was supported by an unrestricted grant from Ipsen. We acknowledge the editorial assistance provided by Martin Gilmour of ESP Bioscience (Crowthorne, UK), supported by Ipsen, during the preparation of this manuscript.
Conflict of interest SM has consulted for Chiasma and Ipsen, and received research grants from Ipsen, Novartis and Pfizer Inc. FFC has been a member of advisory boards for Novartis. AK has received research support from Ipsen and Rhythm Pharmaceuticals. MDB has received honoraria from Ipsen, Novartis and Pfizer as speaker and/or consultant. PC has consulted for Ipsen, Novartis and Pfizer and received research grants from Ipsen, Novartis and Pfizer. SWL has nothing to declare. CJS has received honoraria as an advisory board member from Pfizer, speaker and/or consultant honoraria from Chiasma, Ipsen, Novartis and Pfizer, and research support from Pfizer, Ipsen and Novartis. JAHW has nothing to declare. AG has consulted for Ipsen, Pfizer, and Italfarmaco and has received lecture fees from Novartis and Italfarmaco.

Open Access This article is distributed under the terms of the Creative Commons Attribution License which permits any use, distribution, and reproduction in any medium, provided the original author(s) and the source are credited.

\section{References}

1. Giustina A, Barkan A, Casanueva FF, Cavagnini F, Frohman L, Ho K, Veldhuis J, Wass J, Von Werder K, Melmed S (2000) Criteria for cure of acromegaly: a consensus statement. J Clin Endocrinol Metab 85(2):526-529

2. Giustina A, Barkan A, Chanson P, Grossman A, Hoffman A, Ghigo E, Casanueva F, Colao A, Lamberts S, Sheppard M, Melmed S (2008) Guidelines for the treatment of growth hormone excess and growth hormone deficiency in adults. J Endocrinol Invest 31(9):820-838

3. Giustina A, Casanueva FF, Cavagnini F, Chanson P, Clemmons D, Frohman LA, Gaillard R, Ho K, Jaquet P, Kleinberg DL, Lamberts SW, Lombardi G, Sheppard M, Strasburger CJ, Vance ML, Wass JA, Melmed S (2003) Diagnosis and treatment of acromegaly complications. J Endocrinol Invest 26(12):12421247

4. Giustina A, Chanson P, Bronstein MD, Klibanski A, Lamberts S, Casanueva FF, Trainer P, Ghigo E, Ho K, Melmed S (2010) A consensus on criteria for cure of acromegaly. J Clin Endocrinol Metab 95(7):3141-3148

5. Melmed S, Casanueva F, Cavagnini F, Chanson P, Frohman LA, Gaillard R, Ghigo E, Ho K, Jaquet P, Kleinberg D, Lamberts S, Laws E, Lombardi G, Sheppard MC, Thorner M, Vance ML, Wass JA, Giustina A (2005) Consensus statement: medical management of acromegaly. Eur J Endocrinol 153(6):737-740

6. Melmed S, Casanueva FF, Cavagnini F, Chanson P, Frohman L, Grossman A, Ho K, Kleinberg D, Lamberts S, Laws E, Lombardi G, Vance ML, Werder KV, Wass J, Giustina A (2002) Guidelines for acromegaly management. J Clin Endocrinol Metab 87(9):4054-4058

7. Melmed S, Colao A, Barkan A, Molitch M, Grossman AB, Kleinberg D, Clemmons D, Chanson P, Laws E, Schlechte J, Vance ML, Ho K, Giustina A (2009) Guidelines for acromegaly management: an update. J Clin Endocrinol Metab 94(5): 1509-1517

8. Melmed S (2006) Medical progress: acromegaly. N Engl J Med 355(24):2558-2573

9. Funder JW, Carey RM, Fardella C, Gomez-Sanchez CE, Mantero F, Stowasser M, Young WF Jr, Montori VM (2008) Case detection, diagnosis, and treatment of patients with primary aldosteronism: an endocrine society clinical practice guideline. J Clin Endocrinol Metab 93(9):3266-3281 
10. Guyatt GH, Oxman AD, Vist GE, Kunz R, Falck-Ytter Y, Alonso-Coello P, Schunemann HJ (2008) GRADE: an emerging consensus on rating quality of evidence and strength of recommendations. BMJ 336(7650):924-926

11. Vitale G, Pivonello R, Auriemma RS, Guerra E, Milone F, Savastano S, Lombardi G, Colao A (2005) Hypertension in acromegaly and in the normal population: prevalence and determinants. Clin Endocrinol 63(4):470-476

12. Bihan H, Espinosa C, Valdes-Socin H, Salenave S, Young J, Levasseur S, Assayag P, Beckers A, Chanson P (2004) Longterm outcome of patients with acromegaly and congestive heart failure. J Clin Endocrinol Metab 89(11):5308-5313

13. Cannavo S, Almoto B, Cavalli G, Squadrito S, Romanello G, Vigo MT, Fiumara F, Benvenga S, Trimarchi F (2006) Acromegaly and coronary disease: an integrated evaluation of conventional coronary risk factors and coronary calcifications detected by computed tomography. J Clin Endocrinol Metab 91(10):3766-3772

14. Colao A, Ferone D, Marzullo P, Lombardi G (2004) Systemic complications of acromegaly: epidemiology, pathogenesis, and management. Endocr Rev 25(1):102-152

15. Colao A, Spinelli L, Marzullo P, Pivonello R, Petretta M, Di Somma C, Vitale G, Bonaduce D, Lombardi G (2003) High prevalence of cardiac valve disease in acromegaly: an observational, analytical, case-control study. J Clin Endocrinol Metab 88(7):3196-3201

16. Maffei P, Martini C, Milanesi A, Corfini A, Mioni R, de Carlo E, Menegazzo C, Scanarini M, Vettor R, Federspil G, Sicolo N (2005) Late potentials and ventricular arrhythmias in acromegaly. Int J Cardiol 104(2):197-203

17. van der Klaauw AA, Bax JJ, Roelfsema F, Bleeker GB, Holman ER, Corssmit EP, van der Wall EE, Smit JW, Romijn JA, Pereira AM (2006) Uncontrolled acromegaly is associated with progressive mitral valvular regurgitation. Growth Horm IGF Res 16(2):101-107

18. Andreassen M, Faber J, Kjaer A, Petersen CL, Kristensen LO (2010) Cardiac effects of 3 months treatment of acromegaly evaluated by magnetic resonance imaging and B-type natriuretic peptides. Pituitary 13(4):329-336

19. Ayuk J, Clayton RN, Holder G, Sheppard MC, Stewart PM, Bates AS (2004) Growth hormone and pituitary radiotherapy, but not serum insulin-like growth factor-I concentrations, predict excess mortality in patients with acromegaly. J Clin Endocrinol Metab 89(4):1613-1617

20. Kauppinen-Makelin R, Sane T, Reunanen A, Valimaki MJ, Niskanen L, Markkanen H, Loyttyniemi E, Ebeling T, Jaatinen P, Laine H, Nuutila P, Salmela P, Salmi J, Stenman UH, Viikari J, Voutilainen E (2005) A nationwide survey of mortality in acromegaly. J Clin Endocrinol Metab 90(7):4081-4086

21. Pivonello R, Galderisi M, Auriemma RS, De Martino MC, Galdiero M, Ciccarelli A, D'Errico A, Kourides I, Burman P, Lombardi G, Colao A (2007) Treatment with growth hormone receptor antagonist in acromegaly: effect on cardiac structure and performance. J Clin Endocrinol Metab 92(2):476-482

22. Davi MV, Dalle Carbonare L, Giustina A, Ferrari M, Frigo A, Lo Cascio V, Francia G (2008) Sleep apnoea syndrome is highly prevalent in acromegaly and only partially reversible after biochemical control of the disease. Eur J Endocrinol 159(5): 533-540

23. Colao A, Pivonello R, Grasso LF, Auriemma RS, Galdiero M, Savastano S, Lombardi G (2011) Determinants of cardiac disease in newly diagnosed patients with acromegaly. Results of a 10 year survey study. Eur J Endocrinol 165(5):713-721

24. Colao A, Marek J, Goth MI, Caron P, Kuhn JM, Minuto FM, Weissman NJ (2008) No greater incidence or worsening of cardiac valve regurgitation with somatostatin analog treatment of acromegaly. J Clin Endocrinol Metab 93(6):2243-2248

25. Maison P, Tropeano AI, Macquin-Mavier I, Giustina A, Chanson P (2007) Impact of somatostatin analogs on the heart in acromegaly: a metaanalysis. J Clin Endocrinol Metab 92(5): 1743-1747

26. De Marinis L, Bianchi A, Mazziotti G, Mettimano M, Milardi D, Fusco A, Cimino V, Maira G, Pontecorvi A, Giustina A (2008) The long-term cardiovascular outcome of different GH-lowering treatments in acromegaly. Pituitary 11(1):13-20

27. Maione L, Garcia C, Bouchachi A, Kallel N, Maison P, Salenave S, Young J, Assayag P, Chanson P (2012) No evidence of a detrimental effect of cabergoline therapy on cardiac valves in patients with acromegaly. J Clin Endocrinol Metab. doi: $10.1210 /$ jc. $2012-1833$

28. Colao A (2012) Improvement of cardiac parameters in patients with acromegaly treated with medical therapies. Pituitary 15(1): $50-58$

29. Lafeber M, Stades AM, Valk GD, Cramer MJ, Teding van Berkhout F, Zelissen PM (2010) Absence of major fibrotic adverse events in hyperprolactinemic patients treated with cabergoline. Eur J Endocrinol 162(4):667-675

30. Erem C, Ersoz HO, Ukinc K, Avunduk AM, Hacihasanoglu A, Kocak M (2006) Acromegaly presenting with diabetic ketoacidosis, associated with retinitis pigmentosa and octreotideinduced bradycardia: a case report and a review of the literature. Endocrine 30(1):145-149

31. Sherlock M, Ayuk J, Tomlinson JW, Toogood AA, AragonAlonso A, Sheppard MC, Bates AS, Stewart PM (2010) Mortality in patients with pituitary disease. Endocr Rev 31(3): 301-342

32. Rajasoorya C, Holdaway IM, Wrightson P, Scott DJ, Ibbertson HK (1994) Determinants of clinical outcome and survival in acromegaly. Clin Endocrinol 41(1):95-102

33. Mazziotti G, Floriani I, Bonadonna S, Torri V, Chanson P, Giustina A (2009) Effects of somatostatin analogs on glucose homeostasis: a metaanalysis of acromegaly studies. J Clin Endocrinol Metab 94(5):1500-1508

34. Mazziotti G, Porcelli T, Bogazzi F, Bugari G, Cannavo S, Colao A, Cozzi R, De Marinis L, De Degli Uberti E, Grottoli S, Minuto F, Montini M, Spinello M, Giustina A (2011) Effects of high-dose octreotide LAR on glucose metabolism in patients with acromegaly inadequately controlled by conventional somatostatin analog therapy. Eur $\mathrm{J}$ Endocrinol 164(3):341-347

35. Petersenn S, Schopohl J, Barkan A, Mohideen P, Colao A, Abs R, Buchelt A, Ho YY, Hu K, Farrall AJ, Melmed S, Biller BM (2010) Pasireotide (SOM230) demonstrates efficacy and safety in patients with acromegaly: a randomized, multicenter, phase II trial. J Clin Endocrinol Metab 95(6):2781-2789

36. Grynberg M, Salenave S, Young J, Chanson P (2010) Female gonadal function before and after treatment of acromegaly. J Clin Endocrinol Metab 95(10):4518-4525

37. Katznelson L, Kleinberg D, Vance ML, Stavrou S, Pulaski KJ, Schoenfeld DA, Hayden DL, Wright ME, Woodburn CJ, Klibanski A (2001) Hypogonadism in patients with acromegaly: data from the multi-centre acromegaly registry pilot study. Clin Endocrinol 54(2):183-188

38. van Haute FR, Taboada GF, Correa LL, Lima GA, Fontes R, Riello AP, Dominici M, Gadelha MR (2008) Prevalence of sleep apnea and metabolic abnormalities in patients with acromegaly and analysis of cephalometric parameters by magnetic resonance imaging. Eur J Endocrinol 158(4):459-465

39. Attal P, Chanson P (2010) Endocrine aspects of obstructive sleep apnea. J Clin Endocrinol Metab 95(2):483-495 
40. Sze L, Schmid C, Bloch KE, Bernays R, Brandle M (2007) Effect of transsphenoidal surgery on sleep apnoea in acromegaly. Eur J Endocrinol 156(3):321-329

41. Grunstein RR, Ho KK, Sullivan CE (1994) Effect of octreotide, a somatostatin analog, on sleep apnea in patients with acromegaly. Ann Intern Med 121(7):478-483

42. Herrmann BL, Wessendorf TE, Ajaj W, Kahlke S, Teschler H, Mann K (2004) Effects of octreotide on sleep apnoea and tongue volume (magnetic resonance imaging) in patients with acromegaly. Eur J Endocrinol 151(3):309-315

43. Ip MS, Tan KC, Peh WC, Lam KS (2001) Effect of Sandostatin LAR on sleep apnoea in acromegaly: correlation with computerized tomographic cephalometry and hormonal activity. Clin Endocrinol 55(4):477-483

44. Matta MP, Couture E, Cazals L, Vezzosi D, Bennet A, Caron P (2008) Impaired quality of life of patients with acromegaly: control of GH/IGF-I excess improves psychological subscale appearance. Eur J Endocrinol 158(3):305-310

45. Neggers SJ, van Aken MO, de Herder WW, Feelders RA, Janssen JA, Badia X, Webb SM, van der Lely AJ (2008) Quality of life in acromegalic patients during long-term somatostatin analog treatment with and without pegvisomant. J Clin Endocrinol Metab 93(10):3853-3859

46. Wexler T, Gunnell L, Omer Z, Kuhlthau K, Beauregard C, Graham G, Utz AL, Biller B, Nachtigall L, Loeffler J, Swearingen B, Klibanski A, Miller KK (2009) Growth hormone deficiency is associated with decreased quality of life in patients with prior acromegaly. J Clin Endocrinol Metab 94(7): 2471-2477

47. Killinger Z, Payer J, Lazurova I, Imrich R, Homerova Z, Kuzma M, Rovensky J (2010) Arthropathy in acromegaly. Rheum Dis Clin North Am 36(4):713-720

48. Bonadonna S, Mazziotti G, Nuzzo M, Bianchi A, Fusco A, De Marinis L, Giustina A (2005) Increased prevalence of radiological spinal deformities in active acromegaly: a cross-sectional study in postmenopausal women. J Bone Miner Res 20(10): $1837-1844$

49. Wassenaar MJ, Biermasz NR, Hamdy NA, Zillikens MC, van Meurs JB, Rivadeneira F, Hofman A, Uitterlinden AG, Stokkel MP, Roelfsema F, Kloppenburg M, Kroon HM, Romijn JA, Pereira AM (2011) High prevalence of vertebral fractures despite normal bone mineral density in patients with long-term controlled acromegaly. Eur J Endocrinol 164(4):475-483

50. Podgorski M, Robinson B, Weissberger A, Stiel J, Wang S, Brooks PM (1988) Articular manifestations of acromegaly. Aust N Z J Med 18(1):28-35

51. Biermasz NR, Pereira AM, Smit JW, Romijn JA, Roelfsema F (2005) Morbidity after long-term remission for acromegaly: persisting joint-related complaints cause reduced quality of life. J Clin Endocrinol Metab 90(5):2731-2739

52. Miller A, Doll H, David J, Wass J (2008) Impact of musculoskeletal disease on quality of life in long-standing acromegaly. Eur J Endocrinol 158(5):587-593

53. Colao A, Cannavo S, Marzullo P, Pivonello R, Squadrito S, Vallone G, Almoto B, Bichisao E, Trimarchi F, Lombardi G (2003) Twelve months of treatment with octreotide-LAR reduces joint thickness in acromegaly. Eur J Endocrinol 148(1): 31-38

54. Wassenaar MJ, Biermasz NR, Bijsterbosch J, Pereira AM, Meulenbelt I, Smit JW, Roelfsema F, Kroon HM, Romijn JA, Kloppenburg M (2011) Arthropathy in long-term cured acromegaly is characterised by osteophytes without joint space narrowing: a comparison with generalised osteoarthritis. Ann Rheum Dis 70(2):320-325

55. Mazziotti G, Bianchi A, Bonadonna S, Cimino V, Patelli I, Fusco A, Pontecorvi A, De Marinis L, Giustina A (2008)
Prevalence of vertebral fractures in men with acromegaly. J Clin Endocrinol Metab 93(12):4649-4655

56. Battista C, Chiodini I, Muscarella S, Guglielmi G, Mascia ML, Carnevale V, Scillitani A (2009) Spinal volumetric trabecular bone mass in acromegalic patients: a longitudinal study. Clin Endocrinol 70(3):378-382

57. Mazziotti G, Gola M, Bianchi A, Porcelli T, Giampietro A, Cimino V, Doga M, Gazzaruso C, De Marinis L, Giustina A (2011) Influence of diabetes mellitus on vertebral fractures in men with acromegaly. Endocrine 40(1):102-108

58. Rokkas T, Pistiolas D, Sechopoulos P, Margantinis G, Koukoulis G (2008) Risk of colorectal neoplasm in patients with acromegaly: a meta-analysis. World J Gastroenterol 14(22): 3484-3489

59. Jenkins PJ, Fairclough PD (2002) Screening guidelines for colorectal cancer and polyps in patients with acromegaly. Gut 51(Suppl 5):V13-V14

60. Levin B, Lieberman DA, McFarland B, Andrews KS, Brooks D, Bond J, Dash C, Giardiello FM, Glick S, Johnson D, Johnson CD, Levin TR, Pickhardt PJ, Rex DK, Smith RA, Thorson A, Winawer SJ (2008) Screening and surveillance for the early detection of colorectal cancer and adenomatous polyps, 2008: a joint guideline from the American Cancer Society, the US Multi-Society Task Force on Colorectal Cancer, and the American College of Radiology. Gastroenterology 134(5): $1570-1595$

61. Dworakowska D, Gueorguiev M, Kelly P, Monson JP, Besser GM, Chew SL, Akker SA, Drake WM, Fairclough PD, Grossman AB, Jenkins PJ (2010) Repeated colonoscopic screening of patients with acromegaly: 15-year experience identifies those at risk of new colonic neoplasia and allows for effective screening guidelines. Eur J Endocrinol 163(1):21-28

62. Ayuk J, Sheppard MC (2008) Does acromegaly enhance mortality? Rev Endocr Metab Disord 9(1):33-39

63. Dekkers OM, Biermasz NR, Pereira AM, Romijn JA, Vandenbroucke JP (2008) Mortality in acromegaly: a metaanalysis. J Clin Endocrinol Metab 93(1):61-67

64. Sherlock M, Reulen RC, Alonso AA, Ayuk J, Clayton RN, Sheppard MC, Hawkins MM, Bates AS, Stewart PM (2009) ACTH deficiency, higher doses of hydrocortisone replacement, and radiotherapy are independent predictors of mortality in patients with acromegaly. J Clin Endocrinol Metab 94(11): 4216-4223

65. Melmed S (2009) Acromegaly pathogenesis and treatment. J Clin Invest 119(11):3189-3202

66. Brian SR, Bidlingmaier M, Wajnrajch MP, Weinzimer SA, Inzucchi SE (2007) Treatment of acromegaly with pegvisomant during pregnancy: maternal and fetal effects. J Clin Endocrinol Metab 92(9):3374-3377

67. Cheng S, Grasso L, Martinez-Orozco JA, Al-Agha R, Pivonello R, Colao A, Ezzat S (2012) Pregnancy in acromegaly: experience from two referral centers and systematic review of the literature. Clin Endocrinol 76(2):264-271

68. Caron P, Broussaud S, Bertherat J, Borson-Chazot F, Brue T, Cortet-Rudelli C, Chanson P (2010) Acromegaly and pregnancy: a retrospective multicenter study of 59 pregnancies in 46 women. J Clin Endocrinol Metab 95(10):4680-4687

69. Cozzi R, Attanasio R, Barausse M (2006) Pregnancy in acromegaly: a one-center experience. Eur J Endocrinol 155(2): 279-284

70. Daly AF, Tichomirowa MA, Petrossians P, Heliovaara E, Jaffrain-Rea ML, Barlier A, Naves LA, Ebeling T, Karhu A, Raappana A, Cazabat L, De Menis E, Montanana CF, Raverot G, Weil RJ, Sane T, Maiter D, Neggers S, Yaneva M, Tabarin A, Verrua E, Eloranta E, Murat A, Vierimaa O, Salmela PI, Emy P, Toledo RA, Sabate MI, Villa C, Popelier M, Salvatori R, 
Jennings J, Longas AF, Labarta Aizpun JI, Georgitsi M, Paschke R, Ronchi C, Valimaki M, Saloranta C, De Herder W, Cozzi R, Guitelman M, Magri F, Lagonigro MS, Halaby G, Corman V, Hagelstein MT, Vanbellinghen JF, Barra GB, Gimenez-Roqueplo AP, Cameron FJ, Borson-Chazot F, Holdaway I, Toledo SP, Stalla GK, Spada A, Zacharieva S, Bertherat J, Brue T, Bours V, Chanson P, Aaltonen LA, Beckers A (2010) Clinical characteristics and therapeutic responses in patients with germ-line AIP mutations and pituitary adenomas: an international collaborative study. J Clin Endocrinol Metab 95(11):E373-E383

71. Jaffrain-Rea ML, Daly AF, Angelini M, Petrossians P, Bours V, Beckers A (2011) Genetic susceptibility in pituitary adenomas: from pathogenesis to clinical implications. Exp Rev Endocrinol Metab 6(2): 195-214

72. Vierimaa O, Georgitsi M, Lehtonen R, Vahteristo P, Kokko A, Raitila A, Tuppurainen K, Ebeling TM, Salmela PI, Paschke R, Gundogdu S, De Menis E, Makinen MJ, Launonen V, Karhu A, Aaltonen LA (2006) Pituitary adenoma predisposition caused by germline mutations in the AIP gene. Science 312(5777): $1228-1230$

73. Cazabat L, Libe R, Perlemoine K, Rene-Corail F, Burnichon N, Gimenez-Roqueplo AP, Dupasquier-Fediaevsky L, Bertagna X, Clauser E, Chanson P, Bertherat J, Raffin-Sanson ML (2007) Germline inactivating mutations of the aryl hydrocarbon receptor-interacting protein gene in a large cohort of sporadic acromegaly: mutations are found in a subset of young patients with macroadenomas. Eur J Endocrinol 157(1):1-8

74. Leontiou CA, Gueorguiev M, van der Spuy J, Quinton R, Lolli F, Hassan S, Chahal HS, Igreja SC, Jordan S, Rowe J, Stolbrink M, Christian HC, Wray J, Bishop-Bailey D, Berney DM, Wass JA, Popovic V, Ribeiro-Oliveira A Jr, Gadelha MR, Monson JP, Akker SA, Davis JR, Clayton RN, Yoshimoto K, Iwata T, Matsuno A, Eguchi K, Musat M, Flanagan D, Peters G, Bolger GB, Chapple JP, Frohman LA, Grossman AB, Korbonits M (2008) The role of the aryl hydrocarbon receptor-interacting protein gene in familial and sporadic pituitary adenomas. J Clin Endocrinol Metab 93(6):2390-2401

75. Carlsen SM, Lund-Johansen M, Schreiner T, Aanderud S, Johannesen O, Svartberg J, Cooper JG, Hald JK, Fougner SL, Bollerslev J (2008) Preoperative octreotide treatment in newly diagnosed acromegalic patients with macroadenomas increases cure short-term postoperative rates: a prospective, randomized trial. J Clin Endocrinol Metab 93(8):2984-2990

76. Mao ZG, Zhu YH, Tang HL, Wang DY, Zhou J, He DS, Lan H, Luo BN, Wang HJ (2010) Preoperative lanreotide treatment in acromegalic patients with macroadenomas increases short-term postoperative cure rates: a prospective, randomised trial. Eur J Endocrinol 162(4):661-666

77. Shen M, Shou X, Wang Y, Zhang Z, Wu J, Mao Y, Li S, Zhao Y (2010) Effect of presurgical long-acting octreotide treatment in acromegaly patients with invasive pituitary macroadenomas: a prospective randomized study. Endocr J 57(12):1035-1044

78. Jallad RS, Musolino NR, Kodaira S, Cescato VA, Bronstein MD (2007) Does partial surgical tumour removal influence the response to octreotide-LAR in acromegalic patients previously resistant to the somatostatin analogue? Clin Endocrinol 67(2): 310-315

79. Karavitaki N, Turner HE, Adams CB, Cudlip S, Byrne JV, Fazal-Sanderson V, Rowlers S, Trainer PJ, Wass JA (2008) Surgical debulking of pituitary macroadenomas causing acromegaly improves control by lanreotide. Clin Endocrinol 68(6):970-975

80. Petrossians P, Borges-Martins L, Espinoza C, Daly A, Betea D, Valdes-Socin H, Stevenaert A, Chanson P, Beckers A (2005) Gross total resection or debulking of pituitary adenomas improves hormonal control of acromegaly by somatostatin analogs. Eur J Endocrinol 152(1):61-66
81. Gola M, Bonadonna S, Mazziotti G, Amato G, Giustina A (2006) Resistance to somatostatin analogs in acromegaly: an evolving concept? J Endocrinol Invest 29(1):86-93

82. Buchfelder M (2009) Management of aggressive pituitary adenomas: current treatment strategies. Pituitary 12(3):256-260

83. Colao A, Auriemma RS, Lombardi G, Pivonello R (2011) Resistance to somatostatin analogs in acromegaly. Endocr Rev 32(2):247-271

84. Swords FM, Monson JP, Besser GM, Chew SL, Drake WM, Grossman AB, Plowman PN (2009) Gamma knife radiosurgery: a safe and effective salvage treatment for pituitary tumours not controlled despite conventional radiotherapy. Eur J Endocrinol 161(6):819-828

85. Giustina A, Bronstein MD, Casanueva FF, Chanson P, Ghigo E, Ho KK, Klibanski A, Lamberts S, Trainer P, Melmed S (2011) Current management practices for acromegaly: an international survey. Pituitary 14(2):125-133

86. Clemmons DR (2011) Clinical laboratory indices in the treatment of acromegaly. Clin Chim Acta 412(5-6):403-409

87. Abosch A, Tyrrell JB, Lamborn KR, Hannegan LT, Applebury CB, Wilson CB (1998) Transsphenoidal microsurgery for growth hormone-secreting pituitary adenomas: initial outcome and long-term results. J Clin Endocrinol Metab 83(10): 3411-3418

88. Salaun C, Foubert L, Vialatou M, Kujas M, Turpin G (1999) Prognostic factors in the surgical management of acromegaly. Ann Med Interne 150(3):195-198

89. van der Lely AJ, Harris AG, Lamberts SW (1992) The sensitivity of growth hormone secretion to medical treatment in acromegalic patients: influence of age and sex. Clin Endocrinol 37(2):181-185

90. Asa SL, Digiovanni R, Jiang J, Ward ML, Loesch K, Yamada S, Sano T, Yoshimoto K, Frank SJ, Ezzat S (2007) A growth hormone receptor mutation impairs growth hormone autofeedback signaling in pituitary tumors. Cancer Res 67(15): 7505-7511

91. Jaffrain-Rea ML, Di Stefano D, Minniti G, Esposito V, Bultrini A, Ferretti E, Santoro A, Faticanti Scucchi L, Gulino A, Cantore G (2002) A critical reappraisal of MIB-1 labelling index significance in a large series of pituitary tumours: secreting versus non-secreting adenomas. Endocr Relat Cancer 9(2):103-113

92. Kitz K, Knosp E, Koos WT, Korn A (1991) Proliferation in pituitary adenomas: measurement by MAb KI 67. Acta Neurochir Suppl 53:60-64

93. Zhang X, Horwitz GA, Heaney AP, Nakashima M, Prezant TR, Bronstein MD, Melmed S (1999) Pituitary tumor transforming gene (PTTG) expression in pituitary adenomas. J Clin Endocrinol Metab 84(2):761-767

94. Kiseljak-Vassiliades K, Shafi S, Kerr JM, Phang TL, Kleinschmidt-Demasters BK, Wierman ME (2012) Clinical implications of growth hormone-secreting tumor subtypes. Endocrine 42(1):18-28

95. Bando H, Sano T, Ohshima T, Zhang CY, Yamasaki R, Matsumoto K, Saito S (1992) Differences in pathological findings and growth hormone responses in patients with growth hormoneproducing pituitary adenoma. Endocrinol Jpn 39(4):355-363

96. Ezzat S, Kontogeorgos G, Redelmeier DA, Horvath E, Harris AG, Kovacs K (1995) In vivo responsiveness of morphological variants of growth hormone-producing pituitary adenomas to octreotide. Eur J Endocrinol 133(6):686-690

97. Marazuela M, Paniagua AE, Gahete MD, Lucas T, AlvarezEscola C, Manzanares R, Cameselle-Teijeiro J, Luque-Ramirez M, Luque RM, Fernandez-Rodriguez E, Castano JP, Bernabeu I (2011) Somatotroph tumor progression during pegvisomant therapy: a clinical and molecular study. J Clin Endocrinol Metab 96(2):E251-E259 
98. Mazal PR, Czech T, Sedivy R, Aichholzer M, Wanschitz J, Klupp N, Budka H (2001) Prognostic relevance of intracytoplasmic cytokeratin pattern, hormone expression profile, and cell proliferation in pituitary adenomas of akromegalic patients. Clin Neuropathol 20(4):163-171

99. Ahmed E, Stratton P, Adams W (1999) Outcome of transphenoidal surgery for acromegaly and its relationship to surgical experience. Clin Endocrinol 50(5):561-567

100. Beauregard C, Truong U, Hardy J, Serri O (2003) Long-term outcome and mortality after transsphenoidal adenomectomy for acromegaly. Clin Endocrinol 58(1):86-91

101. Colao A, Attanasio R, Pivonello R, Cappabianca P, Cavallo LM, Lasio G, Lodrini A, Lombardi G, Cozzi R (2006) Partial surgical removal of growth hormone-secreting pituitary tumors enhances the response to somatostatin analogs in acromegaly. J Clin Endocrinol Metab 91(1):85-92

102. De P, Rees DA, Davies N, John R, Neal J, Mills RG, Vafidis J, Davies JS, Scanlon MF (2003) Transsphenoidal surgery for acromegaly in wales: results based on stringent criteria of remission. J Clin Endocrinol Metab 88(8):3567-3572

103. Nomikos P, Buchfelder M, Fahlbusch R (2005) The outcome of surgery in 668 patients with acromegaly using current criteria of biochemical 'cure'. Eur J Endocrinol 152(3):379-387

104. Barkan AL, Halasz I, Dornfeld KJ, Jaffe CA, Friberg RD, Chandler WF, Sandler HM (1997) Pituitary irradiation is ineffective in normalizing plasma insulin-like growth factor I in patients with acromegaly. J Clin Endocrinol Metab 82(10): 3187-3191

105. Cozzi R, Barausse M, Asnaghi D, Dallabonzana D, Lodrini S, Attanasio R (2001) Failure of radiotherapy in acromegaly. Eur J Endocrinol 145(6):717-726

106. Izawa $M$, Hayashi $M$, Nakaya $K$, Satoh $H$, Ochiai $T$, Hori $T$, Takakura K (2000) Gamma knife radiosurgery for pituitary adenomas. J Neurosurg 93(Suppl 3):19-22

107. Arosio M, Macchelli S, Rossi CM, Casati G, Biella O, Faglia G; Italian Multicenter Octreotide Study Group (1995) Effects of treatment with octreotide in acromegalic patients-a multicenter Italian study. Eur J Endocrinol 133(4):430-439
108. Bevan JS (2005) Clinical review: the antitumoral effects of somatostatin analog therapy in acromegaly. J Clin Endocrinol Metab 90(3):1856-1863

109. Clemmons DR, Chihara K, Freda PU, Ho KK, Klibanski A, Melmed S, Shalet SM, Strasburger CJ, Trainer PJ, Thorner MO (2003) Optimizing control of acromegaly: integrating a growth hormone receptor antagonist into the treatment algorithm. J Clin Endocrinol Metab 88(10):4759-4767

110. Ezzat S, Snyder PJ, Young WF, Boyajy LD, Newman C, Klibanski A, Molitch ME, Boyd AE, Sheeler L, Cook DM, Malarkey WB, Jackson I, Vance ML, Thorner MO, Barkan A, Frohman LA, Melmed S (1992) Octreotide treatment of acromegaly. A randomized, multicenter study. Ann Intern Med 117(9):711-718

111. Freda PU (2002) Somatostatin analogs in acromegaly. J Clin Endocrinol Metab 87(7):3013-3018

112. Giusti M, Ciccarelli E, Dallabonzana D, Delitala G, Faglia G, Liuzzi A, Gussoni G, Giordano Disem G (1997) Clinical results of long-term slow-release lanreotide treatment of acromegaly. Eur J Clin Invest 27(4):277-284

113. Abe T, Ludecke DK (2001) Effects of preoperative octreotide treatment on different subtypes of $90 \mathrm{GH}$-secreting pituitary adenomas and outcome in one surgical centre. Eur J Endocrinol 145(2):137-145

114. Colao A, Pivonello R, Auriemma RS, Briganti F, Galdiero M, Tortora F, Caranci F, Cirillo S, Lombardi G (2006) Predictors of tumor shrinkage after primary therapy with somatostatin analogs in acromegaly: a prospective study in 99 patients. J Clin Endocrinol Metab 91(6):2112-2118

115. Lucas T, Astorga R, Catala M (2003) Preoperative lanreotide treatment for $\mathrm{GH}$-secreting pituitary adenomas: effect on tumour volume and predictive factors of significant tumour shrinkage. Clin Endocrinol 58(4):471-481

116. Verhelst JA, Pedroncelli AM, Abs R, Montini M, Vandeweghe MV, Albani G, Maiter D, Pagani MD, Legros JJ, Gianola D, Bex M, Poppe K, Mockel J, Pagani G (2000) Slow-release lanreotide in the treatment of acromegaly: a study in 66 patients. Eur J Endocrinol 143(5):577-584 